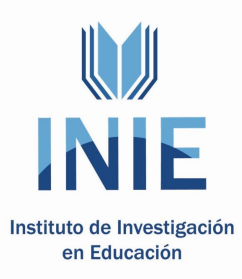

Actualidades Investigativas en Educación

Revista Electrónica publicada por el

Instituto de Investigación en Educación

Universidad de Costa Rica

ISSN 1409-4703

http://revista.inie.ucr.ac.cr

COSTA RICA

\title{
Volumen 10, Número 1
}

pp. $1-26$

Este número se publicó el 30 de abril de 2010

Juan Pablo Zúñiga Vargas

La revista está indexada en los directorios:

LATINDEX, REDALYC, IRESIE, CLASE, DIALNET, DOAJ, E-REVIST@S,

La revista está incluida en los sitios:

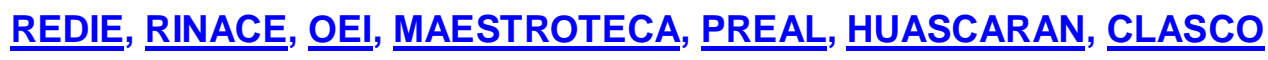




\title{
CONFERENCING VIA E-MAIL: AN ALTERNATIVE WAY TO RESPOND TO STUDENT WRITING LA CONFERENCIA VÍA E-MAIL: UNA MANERA ALTERNATIVA PARA RESPONDER A LOS ESCRITOS DE LOS ESTUDIANTES
}

\begin{abstract}
Juan Pablo Zúñiga Vargas ${ }^{1}$
Abstract: This article reports the findings obtained in a research project that aimed at determining the efficiency of responding to student writing by means of conferencing via e-mail. Such research project was carried out with nine professors from the faculty of engineering and one advanced engineering student at a public university in Costa Rica during the second semester in the year 2008. To collect information for this project, two questionnaires, conferencing forms, instructorsöreflections, and student reflections were used. A reduced number of the students completed the instruments and took part in the conferencing exchanges expected of them, yet both the surveyed students and the instructor found conferencing efficient. Still, more research is needed in order obtain conclusive results about the effectiveness of conferencing via e-mail as an alternative way to respond to student writing. Suggestions for further research are given.
\end{abstract}

Key Words: RESPONDING TO STUDENT WRITING, E-MAIL JOURNALING, CONFERENCING

Resumen: El presente artículo reporta las conclusiones obtenidas en un proyecto de investigación cuyo objetivo fue determinar la eficacia de responder a los escritos de los estudiantes por medio de la conferencia vía correo electrónico. Dicho proyecto de investigación se realizó con nueve profesores de la facultad de ingeniería y un estudiante avanzado de ingeniería de una universidad pública de Costa Rica durante el segundo semestre del año 2008. Para reunir información para tal proyecto se utilizaron dos cuestionarios, formularios para conferencia, reflexiones del instructor y reflexiones de los estudiantes. Un número reducido de los estudiantes completó los instrumentos y participó en la interacción por medio de conferencias que se esperaba de ellos. Aún así, los estudiantes encuestados y el instructor consideraron que el método de la conferencia fue eficaz. No obstante, es necesario realizar más investigación con el fin de obtener resultados concluyentes sobre la efectividad de la conferencia vía correo electrónico para responder a los escritos de los estudiantes. Se ofrecen sugerencias para investigaciones futuras.

Palabras clave: RESPUESTA A LOS ESCRITOS DE LOS ESTUDIANTES, DIARIO POR E-MAIL, CONFERENCIA

\footnotetext{
${ }^{1}$ Magíster en la Enseñanza del Inglés como Lengua Extranjera y Bachiller en Inglés de la Universidad de Costa Rica. Ha impartido cursos de grado y de inglés para otras carreras en la Universidad Nacional. Actualmente imparte cursos de inglés para otras carreras en la Universidad de Costa Rica y ha laborado como docente durante tres años en el Programa de Cursos de Conversación Inglesa de la Escuela de Lenguas Modemas de dicha universidad.
}

Dirección electrónica: juanpablo.zuñiga@ucr.ac.cr

Artículo recibido: 20 de enero, 2010

Aprobado: $1^{\circ}$ de marzo, 2010 


\section{Introduction}

Dealing with student writing presents great challenges to many a language instructor. Writing is a skill that is developed through time. Together with this, the assessment of writing assignments needs to be approached as something more than forming final opinions about them (Zamel, 1985). Consequently, considering writing and the learning of this skill as a process comes to be paramount (Carnicelli, 1980). Following this train of thought, a language instructor can respond to student writing rather than merely assigning a grade to it (Ferris, 2003). In this regard, a research project was carried out aiming at researching into an alternative way to respond to student writing, conferencing via e-mail. In so doing, the following research question guided the development of this project: Is conferencing via e-mail an efficient way for an instructor to respond to student writing in an English for Specific Purposes (ESP) class for engineers?

This project was of great importance to the language instructor developing this study since it allowed him to explore a method commonly used to respond to student writing, conferencing. Conferencing is normally performed by means of oral exchanges between an instructor and a student. The instructor, then, proceeds to discuss a piece of writing with the student who wrote it to highlight its strengths and points that need improvement in order to find solutions together. However, having regular conferencing sessions with students is very time-consuming. This is a limitation if one considers that the ESP course with which this study was conducted was taught during only two hours per session twice a week. Thus, having oral conferencing exchanges with the students would sacrifice valuable class time. Moreover, the students in this ESP course had very busy schedules, so setting up appointments to meet with them outside the class was not feasible. Therefore, using e-mail as a means to implement conferencing emerged as a viable option to do this. All the students had access to computers and the Internet at their workplace, and they checked their e-mail on a daily basis. As an added value, working with electronic documents provides an instructor with more possibilities to modify student writing assignments to give them feedback (e.g., underlining, highlighting, coloring, changing font type, etc.). Aside from this, sometimes students forget about the required format for their written assignments (e.g., spacing and margins), so inserting comments in their writing is very difficult. Electronic documents eliminate this inconvenience together with that of reading studentsôillegible handwriting. As a result of this project, it was expected that the instructor could examine the efficiency of conferencing via e- 
mail to respond to student writing to determine if it can be used as an alternative to have writing conferences with students.

\section{Literature Review}

\subsection{Responding to Student Writing}

In the teaching of writing, an instructor can opt for responding to studentsô written assignments instead of simply grading their work. Responding can occur either orally or in written form, and this method can include both teacher-student response and peer feedback, which are expected to lead to composing different drafts before a final version is handed in (Ferris, 2003). Responding helps both the instructor and the students see writing and its development as a process. Methods including checklists, cassette responses, learner logs, and portfolios can also be used to respond to student writing (Grundy \& Li, 1998), which makes responding very versatile. When responding to student writing, an instructor focuses on the studentsôfulfillment of a written assignment by way of making comments and giving suggestions to improve their writing (Harmer, 2004). The overall accomplishment of a written task comes to be paramount. In addition, a writing instructor needs to be cautious about the way in which he or she responds to student writing. A writing instructor may make the mistake of overlooking the content, organization, and meaning to be found in student writing because of merely focusing on grammar, punctuation, and word choice (Gabrielatos, 2002; Robb, Ross, \& Shortreed, 1986; Zamel, 1985). That is, a writing instructor needs to give more prominence to communication than writing conventions. In this sense, an instructor might be at risk of appropriating student writing and might evaluate it as if it were a final product rather than a work in process (Zamel, 1985). Students have their own way of expressing their ideas in written form, so a writing instructor must not impose his or her style on the students.

Different conclusions have been drawn based on previous research into responding to student writing. Teacher response to student writing causes its desired effect when it is given after the students have spent some time composing texts on their own, and it should also address all aspects of student texts (e.g., grammar, content, and structure), be clear to help students make successful use of it, and consider specific student needs (Ferris, 2003). A writing instructor has to bear in mind such conditions before attempting to respond to student writing. In connection with this, the results reported in a research study carried out by Fathman and Whalley (1990) indicated that teacher response to student writing, be it oriented towards content or grammar, helped students improve their writing in their subsequent Volumen 10, Número 1, Año 2010, ISSN 1409-4703 
rewrites. Teacher response is necessary to encourage students to improve their writing. In addition, responding offers an instructor the possibility of modeling appropriate grammatical and sentence structures in the comments and questions inserted in a written assignment (Mahili, 1994). This constitutes an added value to teacher response.

\subsection{Conferencing}

One productive method to respond to student writing is referred to as conferencing, which deals with the interaction between an instructor and a student in order to provide this student with individualized writing instruction (Brender, 1998; Carnicelli, 1980; Reid, 1993). Conferencing is a method that allows an instructor and a student to work together to improve any piece of writing written by the student. This method helps students polish their writing and fosters negotiation of meaning between the instructor and the student (Goldstein \& Conrad, 1990). In conferences, both the instructor and the student can ask for clarification and give explanations to make themselves understood. In other words, conferencing is an instructional, communicative event in which both the instructor and the student ask and answer questions about the development of a piece of writing (Reid, 1993). For such communicative exchange to be successful, the instructor must first establish the pattern and the guidelines to be followed in the conferencing interaction (Reid, 1993). This will provide an appropriate framework for both the instructor and the student to become acquainted with their roles in conferences. It is also recommended that the students prepare the questions that they would like to ask their instructor in advance (Grundy \& Li, 1998). This may prevent that the students cannot think of what to ask about in conferences. Moreover, two basic principles need to be followed to implement conferencing successfully. First, a writing instructor has to see writing as a process which implies pre-writing, writing, and re-writing. Second, a writing instructor has to be selective as to what aspects he or she wants to focus on in the conferencing exchange, mechanics, organization, style, and so on, in order not to overwhelm the students (Carnicelli, 1980). These principles relate directly to the conclusions drawn from the previous research into responding to student writing.

Responding to student writing by means of conferencing allows an instructor to give feedback to students from different points of view. In conferencing, an instructor can play such roles as coach, judge, facilitator, resource, evaluator, reader, and copy editor (Harmer, 2004; Reid, 1993; Tribble, 1997). A writing instructor does not need to play the same role all the time, which enriches the teaching-learning experience. Additionally, conferencing is a very 
versatile method since it can be used at any stage of the writing process (Grundy \& Li, 1998; Tribble, 1997). Thus, this method can be incorporated in the curriculum of writing courses as a regular activity.

\subsection{Incorporating Conferencing in Writing Instruction: Results}

Different ways to incorporate conferencing in writing instruction have been proposed. An instructor can set up conferencing appointments outside class (Reid, 1993). This can be done if the instructor does not want to allot class time to it. Class time can be allotted to have conferencing exchanges, while the whole group works on a writing task (Watanabe \& Yoshida, 2006). By doing this, the instructor can make sure that students are working on what they are supposed to and supervise them. Conferencing exchanges with the students can also occur on the phone (Carnicelli, 1980) or via e-mail (Mclntyre \& Tlusty, 1995; Wang, 1996). This can be done if it is not possible to meet with the students otherwise. Reference to previous research studies dealing with conferencing as an oral interaction will be made below.

Carnicelli (1980) examined 1,800 student responses from a course evaluation to assess the effectiveness of conferencing and recorded the most recurrent comments. He found that most comments on conferencing were positive although negative comments were made as well. For this reason, he presented a sample of both a successful and a failed conference to indicate that the conferencing method can be as fallible as any other method. Nonetheless, he explained an insightful list of benefits of using the conferencing method, for instance, the effectiveness of individualized instruction over group instruction, the promotion of selflearning, and the instructor $\hat{\Phi}$ efficient use of time. Goldstein and Conrad (1990) conducted a research study with 21 advanced ESL composition students and an experienced ESL instructor. In their study, Goldstein and Conrad wanted to determine to what extent conferencing ensured student input in conferences, to what extent meaning was negotiated in ESL writing conferences, and what the relationship between conferencing and successful

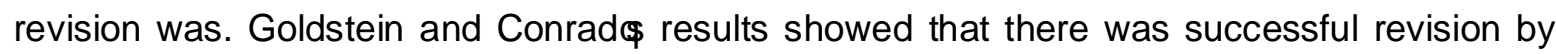
the students after the conferences. Still, the degree to which they produced input and negotiated meaning in conferencing exchanges varied greatly. Presumably, this related to the fact that the students in this study were members of different cultures, and their cultural background might have affected they way in which they perceived the propriety of playing an active role in conferences. In a research study carried out with 20 junior high school students, 
Watanabe and Yoshida (2006) found that conferencing exchanges with an instructor allowed most students to improve the length, content, and grammar in the rewrites and final versions of their compositions, which answered their research hypothesis affirmatively. Watanabe and Yoshida wanted to assess the effects of conferencing on student revision of English compositions. Notwithstanding the results found in the aforementioned studies, one of the drawbacks of face-to-face conferencing is that it is very time-consuming with large groups of students (Grundy \& Li, 1998). For this reason, it is worth considering an innovative, alternative way of implementing conferencing, conferencing via e-mail.

\subsection{Computers, E-Mail, and Conferencing}

Carnicelli (1980) argued that oral response to student writing is more effective than written comments. However, when he wrote his paper, it was almost unthinkable to consider that computers could be used to respond to student writing. Nowadays, with the advent of technological advancements, the use of the computer as a medium to enhance learning cannot be disregarded. Specifically, computer word processors allow students to compose texts more easily by providing spell-checkers, grammar-checkers, and the possibility of adding and deleting sentences to edit their own texts (Pennington, 2003). Computers make texts more flexible and practical to be written and proofread. As a further matter, the use of the e-mail technology to receive, check, and send back studentsôpapers is very convenient for writing instructors since electronic documents are easy to organize and correct, and studentsôelectronic papers can be retrieved at any time for further revision. E-mail is also a good tool to monitor studentsôindividual work (Belisle, 1996). Still, one important limitation to consider when using e-mail in writing classes is that of non-response. This can be attributed to such circumstances as lack of access to computers, lack of engagement in the process, and lack of motivation. The two latter issues, however, can be addressed by sending messages to the students regularly to monitor their work and demonstrate interest in it (Nagel, 1999).

The e-mail technology can be used for conferencing purposes. The way in which conferencing via e-mail can be implemented has been described as occurring in a like manner as journal writing (Brender, 1998). In this sense, e-mail journaling is performed following the same procedure used in paper dialogue journals. The students are assigned a topic about which to write and are asked to send their assignments to their instructor, and then the instructor writes comments on the studentsôwritings by using any piece of e-mail Volumen 10, Número 1, Año 2010, ISSN 1409-4703 
software. Later, the students reply to those comments in the same way (Mclntyre \& Tlusty, 1995; Wang, 1996). Moreover, e-mail journals can be written in a collective fashion in which both the instructor and the students can contribute ideas to a topic under discussion (Yeoman, 1995). In addition to this, e-mail interactions between an instructor and the students or among the students themselves can be either synchronous or asynchronous. That is, participants can interact with one another at a time and manner that are the most convenient for all of them (Berge, 1995).

Specifically designed pieces of software can take part in facilitating electronic conferencing and incorporating it into the curriculum of English language courses (Hui-mei, $\mathrm{n}$. d.). Apart from this, if that type of software is not available, a writing instructor can take advantage of the editing tools found in word-processing computer applications. For instance, $\tilde{n}$ Track Changes,òa tool included in Microsoft Word ${ }^{\circledR}$, allows instructors to make corrections and comments on studentsô electronic documents. Then, the students can use ñTrack Changesòto accept or reject the corrections made by their instructor just by clicking on them (Harmer, 2004).

Despite the fact that research projects dealing with what might be called conferencing via e-mail have been conducted, no reference to projects in which conferencing via e-mail were done by having conferencing exchanges in a single electronic document was found. Keeping track of e-mail interactions among participants of e-mail journaling projects is possible when one is online and has the appropriate piece of software to do so (Mclntyre \& Tlusty, 1995; Wang, 1996). However, having conferencing exchanges in the same document that is being dealt with might prove useful to keep a handy record of the electronic interactions between an instructor and a student. Therefore, it can be argued that more research into this way of implementing conferencing is needed. This was the procedure followed in the conducted research project.

\section{Method}

\subsection{Participants}

Ten subjects (nine males and one female) participated in this research project. Specifically, this population included nine professors from the faculty of engineering and one advanced engineering student from a public university in Costa Rica. The professorsôarea of expertise was agricultural engineering. The student mentioned previously was majoring in 
agricultural engineering at that time. All of them were native speakers of the Spanish language. Their English level was intermediate or advanced.

\subsection{The context of the study}

This research project was a carried out as part of a graduation project for a master $\hat{\mathbf{S}}$ degree program in the teaching of English as a foreign language at a public university in Costa Rica. This graduation project consisted of conducting a needs analysis with a specific student population at this university, designing an ESP course, and teaching it. This course had an agricultural engineering emphasis and a strong writing focus since this was found out after conducting the needs analysis. This project took place during the second half of the second semester in the year 2008.

\subsection{Materials}

For the purpose of communicating with the students who participated in this project, an e-mail account provided by the university was used since nine of the students also had university e-mail accounts. This was done aiming at avoiding incompatibility problems between the instructor $\hat{\Phi}$ and the studentsôe-mail accounts. In order to obtain data and validate the results of this project, the following instruments were used:

\section{A first questionnaire,}

\section{Conferencing forms,}

3. The instructorös reflections,

4.Student reflections, and

\section{A second questionnaire.}

Each instrument will be described briefly below:

1. Questionnaire 1 (See Appendix A): This was a short Spanish questionnaire intended to collect general information about the studentsôprevious experience in writing in English and having someone respond to it. This instrument was sent to the students via e-mail.

2. Conferencing forms (See Appendix B): This instrument served the purpose of establishing the pattern to be followed by the instructor and the students in the conferencing exchanges. A conferencing form was pasted at the bottom of the Volumen 10, Número 1, Año 2010, ISSN 1409-4703 
electronic documents that the students sent to the instructor to keep track of all the exchanges made. Aside from this, corrections were inserted in the studentsôwritten assignments using the tool called ñTrack Changesòincluded in Microsoft Office Word (B).

3. Instructorös reflections (See Appendix C): This instrument was an introspective way to collect information about the instructorês impression about conferencing via email and its efficiency. An instructor $\hat{\boldsymbol{s}}$ reflection was written right after the instructor checked the studentsôpapers, inserted comments in them, and sent them back to the students.

4. Student reflections (See Appendix D): This instrument was designed to collect data about the studentsô point of view about conferencing via e-mail and its efficiency. It was written in Spanish to allow students to express their opinions freely. This instrument was sent to the students via e-mail.

5. Questionnaire 2 (See Appendix E): Due to the fact that a limited number of students sent their written assignments to have conferencing exchanges, a second questionnaire was designed. This was a four-item instrument intended to collect information about the studentsô possible reasons for not taking part in the conferencing exchanges. This instrument was administered at the end of a class.

\subsection{Procedure}

The steps below were followed to carry out the conducted research project:

1. Collection of information about conferencing and responding to writing: Information dealing with responding to student writing and conferencing began to be collected on September $14^{\text {th }}$, and this process actually continued throughout the second half of the semester as more issues related to the topic at hand emerged.

2. Design of instruments to collect data from the students: Instruments were designed from September $14^{\text {th }}$ through September $21^{\text {st }}$. Still, the second questionnaire used in this research project was designed on November $1^{\text {st }}$.

3. Delivery of instructions for the written assignments to start the conferencing exchanges: Instructions for the written assignments were sent to the students via email on September $24^{\text {th }}$.

4. Implementation of conferencing: Conferencing started when the first student assignment was received. This was on September $28^{\text {th }}$. 
5. Instructorös reflections: The instructor wrote his first reflection on September $30^{\text {th }}$.

6. Application of the first questionnaire: This instrument was sent to the students via e-mail on October $1^{\text {st }}$. The first three questionnaires were received on October $2^{\text {nd }}$.

7. Student reflections: The student reflection form was sent to the students via e-mail on October $22^{\text {nd }}$. The first student reflection was received on October $30^{\text {th }}$.

8. Application of the second questionnaire: This instrument was administered in class on November $5^{\text {th }}$.

9. Analysis and organization of results: This process took place from November $2^{\text {nd }}$ through November $15^{\text {th }}$.

10. Presentation of project: This project was submitted to the professor in charge of evaluating it on November $19^{\text {th }}$.

\subsection{Analysis}

After the application of all the instruments described above, the information obtained from them was compared and categorized into different sections to evaluate the efficiency of conferencing via e-mail. Specifically, the information obtained was classified according to the studentsô experience with English writing and instructor response, difficulty with English writing, and assessment of conferencing via e-mail. The instructor $\hat{\boldsymbol{s}}$ assessment of conferencing via e-mail and an analysis of student participation in the study were also included.

\section{Intervention Process}

To complement their professional qualifications, the students in the ESP course in question needed to practice how to compose journal articles. Therefore, in the second and largest unit of the course, the students worked on writing the first sections of a journal article (i.e., title, introduction, literature review, and method). Each student freely chose his or her own topic to develop such sections. In the ESP course, the students were taught and provided with practice in composition principles and formatting and styling conventions generally used in journals of their academic field. In addition, they were given frameworks to articulate their ideas and start composing the different sections of their journal articles. This part of the process included both in-class activities and homework assignments. Those activities and assignments were to be handed in printed or in hand-written form. The idea behind this previous training was that the students were equipped with tools to write Volumen 10, Número 1, Año 2010, ISSN 1409-4703 
confidently in English and had a rough draft of their journal articles before actually having any conferencing exchanges with the instructor. This was done to allow the students to have a working piece of writing that they could modify and improve during the development of the conducted research project. Then, as part of their homework assignments, the students were requested to send the drafts of their journal articles to their instructor in electronic form via email. After that, the conferencing exchanges started using the conferencing forms described in the method section. In this part of the process, each of the students was expected to improve his or her piece of writing after having conferencing exchanges with the instructor and send this new version to the instructor. Later, the instructor would read the new version sent to him and send a response to the student who wrote it so that he or she could improve it once more. This was intended to occur as many times as possible to obtain the most learning gains.

\section{Results and Discussion}

Before presenting the results obtained in the conducted research project, it must be pointed out that a reduced number of students took part in the conferencing exchanges and in the collection of data. Indeed, five out of the ten students sent their written assignments to the instructor, and out of those five students, only two had actual conferencing exchanges with the instructor. Five out of the ten students completed the first questionnaire, and only two out of the ten students completed the student reflection form. The same happened when the second questionnaire was administered; only two out of the five students who did not send their written assignments completed this instrument (See Table 1). The five students who sent their written assignment were not necessarily the same students who completed the first questionnaire, nor were the two students who fully participated in the conferencing exchanges necessarily the same ones who completed the student reflection form. For this reason, no other figures will be used to present the results obtained. Moreover, it must be pointed out that the ESP course with which this research project was conducted was not a required one. Every year, ESP courses are designed for different populations at the university. Such courses are not part of any educational program. What is more, students do not have to pay for those courses or register them officially. Together with this, the students were not given any grade for participating in the conferencing exchanges implemented in this project. These facts might have also affected the results obtained in the conducted research project. 
TABLE 1

Number of Students Who Participated in the Collection of Data

\begin{tabular}{lccccc}
\hline & $\begin{array}{c}\text { Written } \\
\text { Assignment }\end{array}$ & $\begin{array}{c}\text { Conferencing } \\
\text { Exchanges }\end{array}$ & $\begin{array}{c}\text { Questionnaire } \\
\text { Number }\end{array}$ of & $\begin{array}{c}\text { Student } \\
\text { Reflection }\end{array}$ & $\begin{array}{c}\text { Questionnaire } \\
\text { Students }\end{array}$ \\
5 & 5 & 2 & 5 & 2 & 2 \\
\hline
\end{tabular}

\subsection{StudentsöExperience with English Writing and Instructor Response}

In the first questionnaire, two out of the five students who completed this instrument said that they had received training in English writing previously. The other three said that they had not received such training. Interestingly enough, the students who received previous training said that their instructor did not give them suggestions to improve their writing. Nonetheless, four out of the five students said that they look for someone else $\hat{\boldsymbol{s}}$ opinion about any text that they write in English. The reasons that they gave for this were that professional publications need to be well-written, that it is a way to have someone who knows the English language check if one $\hat{\Theta}$ sentences are coherent and grammatical, that it is always

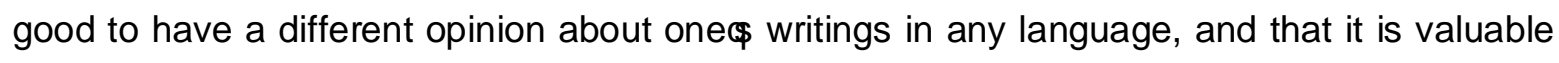
to have someone who knows English give feedback about one $\hat{\mathbf{s}}$ writing. The student who said that he does not look for another personôs opinion about his writing said that it is because he has not written anything in English yet. Still, even this student added that it is

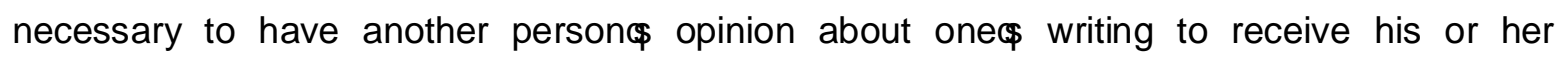
suggestions to make corrections before submitting a paper to its final reader.

Despite the fact that the five surveyed students have not experienced formal response to their writing by any writing instructor, four of them have looked for response to their writing otherwise. All the five surveyed students said that it is important to look for someone else $\hat{\mathbf{s}}$ opinion about their writing. This can be related to the fact that many roles can be played when responding to writing (Harmer, 2004; Reid, 1993; Tribble, 1997). Such roles are generally played by a writing instructor. However, based on the answers given by the students about why they look for other people $\hat{\boldsymbol{s}}$ opinions about their writing, it can be argued that their peers have actually played the roles of readers, judges, evaluators, and copy editors. In this sense, 
the surveyed students can be said to have experience with response to writing and to be receptive to it.

\subsection{StudentsöDifficulties with English Writing}

Concerning the difficulties with English writing faced by the students, the five students who answered the first questionnaire gave similar answers. The five of them mentioned use of adequate vocabulary, punctuation, sentence structure, use of articles, use of verbs, and spelling. The method that was followed to deal with the studentsôdifficulties was that of being selective (Carnicelli, 1980). Thus, while responding to student writing, the instructor focused only on some of the most salient problems found in the studentsôwritten assignments. Nonetheless, as mentioned at the beginning of this section, this process did not go as expected because only five out of ten students sent their written assignments to the instructor, and only two out of those five had conferencing exchanges with him. The only point that was not addressed in the responses given to the students was vocabulary use, for it fell apart from the instructor $\hat{\boldsymbol{s}}$ area of expertise due to the specific terminology used by the population with which this project was carried out.

\subsection{Instructorös Assessment of Conferencing via E-Mail}

After comparing the information recorded in the conferencing forms and the instructor $\hat{\mathbb{S}}$ reflections, it can be said that conferencing via e-mail was efficient. In the instructor $\hat{\Phi}$ reflections, words such as r̃speed,ò r̃ease,ò r̃ romfort,ò and r̃̃onvenienceò were recurrently written to describe the instructor $\hat{\Phi}$ impressions about conferencing via e-mail. The instructor even admitted that for him, writing on a computer was faster than responding to students using a pen or a pencil. In addition, the use of conferencing forms can be highlighted as having constituted an aid for both the instructor and the students to focus on the communicative exchange that was expected of them. That is, the idea of establishing the pattern and guidelines to be followed in conferencing proposed by Reid (1993) proved useful. It can be argued that using the conferencing forms helped both the instructor and the students not to divert from the course of the conferencing exchanges. What is more, it is possible to identify a sequence in the interactions made by both the instructor and the two students who did take part in the conferencing exchanges. Basically, the students inquired about writing and styling conventions. 
In terms of efficiency, the instructor at first wrote rather long comments on the conferencing forms and tried to focus on a little too many different writing aspects at the same time. Still, in subsequent revisions, the instructor started focusing on two or three of the most salient points that needed improvement in the studentsôwritten assignments. This directly relates to the second conferencing principle delineated by Carnicelli (1980), to be selective as to what aspects to focus on in student writing. More research is needed to determine how many aspects should be dealt with at a time for the students to get the most learning gains. Furthermore, in one of his reflections, the instructor acknowledged that he had to fight his ñnstructor $\hat{\Phi}$ appropriation urge.ò Appropriating student writing is an important point to cope with when responding to written assignments as described by Zamel (1985). Appropriating student writing using electronic documents is indeed much easier than doing so in paper. Word-processing pieces of software offer multiple possibilities to modify documents (Pennington, 2003). This had to be born in mind while responding to student writing via email. As put by the instructor in one of his reflections, $\tilde{n}$ tried to respect the way in which they wrote their ideas as much as possible.ò

\subsection{StudentsöAssessment of Conferencing via E-Mail}

In the reflections of the two students who completed this instrument, favorable opinions about conferencing via e-mail were given. The first student said that this method helped him improve his writing. This student reported that conferencing was an interactive way of learning and realizing one $\hat{\boldsymbol{s}}$ mistakes. This student wrote that knowledge was transmitted in a more personalized fashion in the course, and there was more freedom of expression. This student mentioned that this type of interaction was satisfactory and flexible to send and check corrections. This student also suggested that it would be even more useful to insert comments on errors right in the section of the text where those errors were made by means of ñTrack Changes. òThe second subject who completed the student reflection said that this method was clear, effective, and prompt. In fact, this student wrote that it was advantageous to be able to check the given feedback at the time that he wanted to. This student also suggested that logs could be included as part of the conferencing exchanges. This would help to keep a record of the mistakes made by students and their possible corrections. In addition, this student mentioned that the instructorếs comments were easy to understand, yet interaction was reduced in his opinion. 
Considering the advantages referred to by those two students, it can be pointed out that they are consistent with what the literature on the topic at hand poses for consideration. Conferencing allows writing instructors to give personalized feedback (Brender, 1998; Carnicelli, 1980; Reid, 1993). Electronic communication can be asynchronous. That is, participants are free to decide when they want to participate in the intended interactions (Berge, 1995). An instructor can retrieve studentsôpapers at any time for further revision (Belisle, 1996). In fact, this was also true for the students.

Regarding the suggestions made by the surveyed students, inserting direct comments where errors are found using ñTrack Changesòis possible (Harmer, 2004). This can be taken into consideration for future research studies into this topic. Moreover, the issue of reduced interaction is one of the limitations of using e-mail considered by Nagel (1999). An instructor needs to show that he or she is committed to this way of working by responding to the studentsô regularly. The student who wrote the aforementioned comment might have expected more interaction with the instructor than it occurred in his opinion.

\subsection{Non-Response by the Students}

The second questionnaire used in this project was designed to collect information about the reasons why five students did not send their written assignments. As mentioned at the beginning of this section, only two out of those five students were present when this questionnaire was administered. In this questionnaire, the students were first asked whether they had ever used e-mail to check their studentsôwritten reports. The first student said that she does not use e-mail to check studentsôpapers because they might say that their reports were not received due to technical problems. However, this student said that she has checked theses and research projects via e-mail. The second student wrote that he has done that a couple of times because of studentsôproblems to hand in their reports personally. Then, the surveyed students were asked why they did not send their written assignments via e-mail. The two of them responded that they did not have time to do that because of their jobs.

In the following question, the students were asked if they would have preferred to keep on sending their assignments in printed form and receiving hand-written comments from their instructor. The first student said that she preferred electronic communication. This student also wrote that printing documents was difficult for her. The second student mentioned that he 
prefers communication via the Internet because it is convenient, yet if the student fails to do his part, there is no communication.

In the last question, the students were welcome to make suggestions about how to have an efficient instructor-student electronic communication system. The first student wrote that the instructor was willing to work using this system. Still, this student could not be part of if because of her multiple duties for which to be responsible. The second student said that he would not make any suggestion but wrote, ñThe student has to know his share of responsibility as well as the instructor once an assignment has been given.ò

The main reasons for implementing conferencing via e-mail were that time would be a constraint and that all the students had access to computers and the Internet at their workplace. Based on the answers given by the two surveyed students, they had had previous experience checking studentsôpapers via e-mail, so this was not anything new for them. However, it can be contended that their job-related responsibilities outweighed their student responsibilities.

This finding is consistent with that obtained by Mclntyre \& Tlusty (1995). Mclntyre \& Tlusty carried out a study with eleven university student teachers during one semester. Their study aimed at examining the nature and use of electronically mediated discourse by way of e-mail dialogue journaling. In their study, Mclntyre \& Tlusty found that despite the fact that students took active part in the e-mail journaling exchanges, their messages decreased throughout the semester. Through a survey, it was found out that the studentsô other responsibilities contributed to the decrease in their e-mail journaling exchanges.

Similarly, in the conducted research project, the studentsô responsibilities were an obstacle to achieving the desired outcomes. Indeed, there was a point in which none of the students was interacting with the instructor. The issue of non-response in electronic communication is discussed by Nagel (1999). To deal with this, he suggests that the instructor should respond to the messages received regularly to show commitment to the process. In this project, the instructor responded to his studentsômessages one day after they were received at the latest. In addition, he sent frequent e-mail messages to the students to inquire about the development of their assignments. In addition, the instructor sent two ebooks and links to web pages to the students with information that was of use to their assignments. The instructor attempted to demonstrate his commitment to and interest in his studentsôwork, yet the problem of non-response could not be rectified. 


\section{Conclusions}

The conclusions presented in this section were reached after analyzing the information collected from the instructor and the students who did take part in the collection of data. Notwithstanding, the reduced number of active participants in the conducted research project makes it impossible to refer to a definite trend or generalization, so the findings included here are by no means conclusive. More research into conferencing via e-mail is needed in order to obtain thorough evidence about the efficiency of this method of responding to student writing.

Conferencing via e-mail is a convenient method to give students personalized instruction. By working with each of the studentsôpapers individually, the instructor could see what his studentsôwriting strengths and weaknesses were. Then, the instructor was able to identify his students ôneeds, cater for them, and encourage his students to work on them. This is less probable to occur if a writing instructor assigns grades to his or her studentsôpapers. A grade implies the end to an assignment; nothing else can be done to change it. On the contrary, if students are welcome to see writing as a process that implies drafting, revising, and re-writing, they will be able to see that they can progress and improve their writing. Each student writes differently and has different difficulties, so having conferencing exchanges with them is a way to approach their particular needs seeking to achieve learning gains. The students could see that and showed it in the conferencing forms and in the student reflection forms.

Writing on a computer is fast and easy. This is something of which both the instructor and the students can take advantage. Working with electronic documents allows users to include a wide range of modifications to edit their writing. In addition, checking electronic documents is practical for a writing instructor since he does not have to be afraid of making mistakes, while reading his studentsôassignments. If the instructor misinterprets a portion of a student $\hat{\boldsymbol{\Theta}}$ text and includes a wrong correction, he can simply delete it, and nobody but him will know that this mistake was made. Together with this, using e-mail to send and receive studentsôpapers guarantees immediate delivery and interaction outside the classroom. Even if students miss classes, they can still get in contact with their instructor via e-mail, or their instructor can send their checked assignments via e-mail for the students to work on them before the next class.

The successful implementation of conferencing via e-mail depends upon a number of desirable circumstances. Both the instructor and the students need to be knowledgeable about computers, the Internet, and e-mail, and they need to be willing to try this way of Volumen 10, Número 1, Año 2010, ISSN 1409-4703 
working. Otherwise, a preliminary induction process would be needed. Aside from this, all the participants in conferencing via e-mail need to have access to computers, the Internet, and email accounts. What is more, participants need to check their e-mail regularly to ensure effective communication among them. If such conditions are not met, conferencing via e-mail will be subject to failure. As a further matter, both the instructor $\hat{\boldsymbol{\Theta}}$ and the studentsô commitment to having conferencing exchanges via e-mail comes to be crucial for this method to work as intended. In conclusion, both technical and human factors interfere with conferencing via e-mail.

\section{Limitations}

The researcher wants to acknowledge a series of limitations that might have been an obstacle to the development of the conducted research project and the efficient collection of data needed for it:

1. The period of time during which this project was carried out might not have been propitious for its implementation. This research project took place during the second half of the second semester in the year 2008. In other words, this project lasted eight weeks approximately. During this time, strict deadlines had to be met in order to complete this project. Thus, neither the instructor nor the students had much time to take part in this research project.

2. Student participation was a key issue in the collection of data for this project. A very limited number of students participated in this project owing to job-related responsibilities presumably. For this reason, it was not possible to survey the total intended student population, and the results obtained cannot be deemed definitive.

3. The researcher believes that there was a problem in the way in which guidelines were given to the students. After receiving the response sent by their instructor, the students were expected to read the comments and suggestions included in the conferencing forms, edit their assignments, and send them back to their instructor together with their reply to those comments. The instructor included the instructions for the students to edit their assignments in one of the sections of the conferencing forms. However, it appears that the students overlooked this part of the process. This should have been part of the instructions written at the top of the conferencing forms.

4. When working with technology, bearing interoperability in mind is important. Interoperability refers to compatibility between computers or pieces of software. Volumen 10, Número 1, Año 2010, ISSN 1409-4703 
Newer versions of certain computer programs may not be interoperable with older versions of the same piece of software. To illustrate, the instructor faced interoperability problems when he received one of his students written assignments. That paper had been created using the latest version of Microsoft Word $\AA$, which is not compatible with older versions of this application if files are not previously converted into an older format. Thus, the instructor had to look for a computer which had that software version to convert the file into a format that his computer could open to be able to read it. Also, the capabilities of the tool ñTrack Changesòvary depending on its version.

\section{Recommendations for Further Research}

For future research projects about conferencing via e-mail, the following recommendations can be taken into consideration:

1. Conferencing via e-mail could be studied by analyzing information obtained from different groups of students. A sample group and a control group might also serve this purpose. Working with different groups of students might prove useful to collect enough data to obtain more conclusive findings about the effectiveness of the e-mail conferencing method.

2. In the conducted research project, only one method to implement conferencing was used. In future research projects, the option of comparing and contrasting conferencing methods might be considered. The aim of this research project was to examine the efficiency of conferencing via e-mail to respond to student writing. However, this method could be compared and contrasted to face-to-face conferencing to determine which of the two ways of implementing it is the most efficient.

3. The tool called ñTrack Changesòwas used to give feedback to students in this project. Nonetheless, the effectiveness of the use of other word-processing tools could be assessed in future research projects. For example, a color code could be devised to respond to student writing in electronic form, and this code could be compared and contrasted with ñTrack Changesòto determine whether any of the two helps students improve their writing better. The clarity of the color code and ñTrack Changesòcould also be measured to see which of the two is the most practical to respond to student writing electronically. 
4. Nowadays, students can enroll in distance education programs as an alternative to regular education programs. Distance education programs are currently offering online courses, and this might prove a suitable environment to implement conferencing via email and study the impact of this method on students taking distance courses.

5. Aside from monitoring studentsôwork and sending them e-mail messages regularly, a writing instructor might consider the option of assigning grades or points to conferencing exchanges. A grade could encourage students to participate in conferencing because there would be an obvious reward for it. In contrast, instead of getting a grade, students could be given extra points for taking part in the conferencing exchanges. Then, students could use these extra points to compensate for missing assignments or missing classes and get a better grade at the end of a course.

\section{References}

Belisle, Ron. (1996). E-mail activities in the ESL writing class. The Internet TESL Journal, II (12). Retrieved May 3, 2008, from http://iteslj.org/Articles/Belisle-Email.html

Berge, Zane. L. (1995, January-February). Facilitating computer conferencing: Recommendations from the field. [Electronic Version]. Educational Technology, 2230 .

Brender, Alan. (1998). Conferencing: An Interactive Way to Teach Writing. The Language Teacher Online. Retrieved May 3, 2008, from http://www.jaltpublications.org/tlt/files/98/jul/brender.html

Carnicelli, Thomas. A. (1980). The writing conference: A one-to-one conversation. In T. Donovan \& B. McClelland (Eds.), Eight Approaches to Teaching Composition (pp.101-131). Urbana, IL: National Council of Teachers of English.

Ferris, Dana. (2003). Responding to writing. In B. Kroll (Ed.), Exploring the Dynamics of Second Language Writing (pp.119-140). New York: Cambridge University Press.

Fathman, Ann. K. \& Whalley, Elizabeth. (1990). Teacher response to student writing: Focus on form versus content. In B. Kroll (Ed.), Second Language Writing (pp.178-190). New York: Cambridge University Press.

Gabrielatos, Costas. (2002). EFL Writing: Product and Process. Retrieved May 3, 2008, from http://www.geocities.com/cgabrielatos

Goldstein, Lynn. M. \& Conrad, Susan. M. (1990). Student input and negotiation of meaning in ESL writing conferences. Tesol Quarterly, 24 (3), 443-460. 
Grundy, Peter. \& Li, Vivian. (1998). Responding to Writing: Options and Alternatives. Retrieved September 6, 2008, from http://www.brasyl.co.uk/emesh//members/teachers/pdf/tc art writing002.pdf

Harmer, Jeremy. (2004). How to Teach Writing. Edinburgh: Longman.

Hui-mei, Justina. H. (n. d.). Enhancing Writing with Student-Teacher Writing Conferencing Software. Retrieved October 21, 2008, from http://www.iltce.org/present04/hsu.pdf

Mahili, Iphigenia. (1994, October). Responding to student writing. [Electronic Version]. English Teaching Forum, 24-27.

McIntyre, Susan. R. \& Tlusty, Roger. H. (1995). Computer-mediated discourse: Electronic dialogue journaling and reflective practice. San Francisco, CA: Paper Presented at the Annual Meeting of the American Research Association. (ERIC Document Reproduction Service No. ED385232)

Nagel, Pieter. S. (1999). E-mail in the virtual ESL/EFL classroom. The Internet TESL Journal, V (7). Retrieved October 21, 2008, from http://iteslj.org/Articles/NagelEmail.html

Pennington, Martha. C. (2003). The impact of the computer in second language writing. In B. Kroll (Ed.), Exploring the Dynamics of Second Language Writing (pp.287-310). New York: Cambridge University Press.

Reid, Joy. M. (1993). Teaching ESL Writing. New Jersey: Prentice-Hall, Inc.

Robb, Thomas., Ross, Steven., \& Shortreed, Ian. (1986). Salience of feedback on error and its effect on EFL writing quality. Tesol Quarterly, 20 (1), 83-95.

Tribble, Christopher. (1997). Writing. New York: Oxford University Press.

Wang, Yu-mei. (1996). E-mail dialogue journaling in an ESL reading and writing classroom. Indianapolis, IN: Proceedings of Selected Research and Development Presentations at the 1996 National Convention of the Association for Educational Communications and Technology. (ERIC Document Reproduction Service No. ED397845)

Watanabe, Kazuo. \& Yoshida, Kumiko. (2006). Effects of Conferencing on Revision in EFL Writing: A Case Study of Japanese Junior High School Students. Retrieved September 6, 2008, from http://www.nara-edu.ac.jp/CERT/bulletin2006/b2006-H05.pdf

Yeoman, Elizabeth. (1995). "Sam's cafe:" A case study of computer conferencing as a medium for collective journal writing. Canadian Journal of Educational Communication, 24 (3), 209-226.

Zamel, Vivian. (1985). Responding to student writing. Tesol Quarterly, 19 (1), 79-101. 


\section{Appendixes}

\section{Appendix A \\ Cuestionario 1: Experiencia con la Escritura en Inglés}

Instrucciones: El siguiente cuestionario pretende recabar información acerca de su experiencia con la escritura en la lengua inglesa. La información plasmada en este instrumento se mantendrá en absoluta confidencialidad Para completar este instrumento, se le solicita leer cada ítem y responder de manera sincera y precisa. Marque con una equis $(X)$ en los ítems de Si o No.

1. ¿Ha recibido algún tipo de capacitación para escribir en inglés?

Si

No (Pase a la pregunta 3)

2. ¿Su profesor le daba algún tipo de sugerencias para mejorar su escritura en inglés?

$\mathrm{Si}$ No

3. ¿Busca usted a alguna persona para que le de su opinión acerca de algún texto que haya redactado en inglés?

$\mathrm{Si}$ No___ (Pase a la pregunta 5)

4. ¿Considera usted valioso el buscar la opinión de otra persona hacia sus escritos en inglés? ¿Por qué?

5. Si respondió No en la pregunta 3, ¿Por qué motivo(s) no busca la opinión de otra persona hacia sus escritos en inglés?

6. ¿Cuáles dificultades enfrenta usted a la hora de redactar un texto en inglés? 


\section{Appendix B \\ Conferencing Form}

Instructions: In the following chart, your instructor will write comments and suggestions about your writing. Such comments and suggestions will be organized in different sections. In addition, you will have the opportunity to reply to your instructor $\hat{\boldsymbol{\Theta}}$ comments in section $\mathbf{4}$ of this chart. To do this, type your comments or questions, save the changes, and send this file back to your instructor via e-mail.

1. What is really good about your writing is...

2. What can be even better in your writing is...

3. You need to work on...

4. Your reply (In this section, feel free to reply to the previous comments. For example, you can ask for clarification and extra suggestions, ask questions, or comment on the process of working on this piece of writing.)

5. My response (Here, I will respond to the questions you ask or the comments you make above.) 


\section{Appendix C Instructorös Reflection on Conferencing Via E-mail}

1. After responding to my studentsôwriting via e-mail, I felt...

2. Something that I like about the way I responded to my studentsôwriting is...

3. Something I would change about the way I responded to my studentsôwriting is...

4. In my opinion, how efficient has conferencing via e-mail been up to this time?

5. Does conferencing via e-mail really save time? Why?

6. Other comments: 


\section{Appendix D \\ Reflexión}

Instrucciones: Luego de haber recibido comentarios acerca de su redacción en inglés de manera electrónica, medite sobre esta experiencia. Aquí encontrará una serie de enunciados incompletos. Lea cuidadosamente, reflexione y complete cada uno de manera sincera. La información plasmada en este documento se mantendrá en absoluta confidencialidad.

1. Al leer los comentarios hechos por mi profesor, yo penséé

2. Tener este tipo de interacción por correo electrónico con mi profesor esé

3. En términos de tiempo y conveniencia, este tipo de interacción ha sidoé

4. Algo positivo sobre esta interacción electrónica ha sidoé

5. Algo que podría mejorar en esta interacción electrónica esé

6. Con respecto a la facilidad para incorporar los comentarios, cambios y sugerencias de mi profesor, esta modalidad de trabajo ha sidoé 


\section{Appendix E \\ Cuestionario 2: \\ Comunicación Electrónica Profesor-Alumno}

Instrucciones: Este instrumento pretende recabar información acerca de la comunicación electrónica profesor-alumno que se ofreció durante la segunda mitad del semestre. Lea cada ítem y responda de manera clara y sincera. Marque con una equis $(X)$ en el ítem de opción múltiple. La información recolectada en este instrumento se mantendrá en estricta confidencialidad.

1. ¿Ha utilizado el correo electrónico para revisar trabajos escritos de sus estudiantes alguna vez? ¿Por qué?

2. En la segunda mitad de este semestre, su profesor le solicitó que enviara sus trabajos escritos por medio electrónico. Si no los envió, ¿Cuál fue la razón de esto?

( ) No me pareció importante.

( ) No tuve tiempo para hacerlo por mi trabajo.

( ) Las instrucciones dadas no fueron claras.

( ) No tenía acceso a Internet.

( ) Otro (Especifique):

3. ¿Hubiera preferido seguir entregando sus trabajos impresos y recibir correcciones hechas a mano por parte de su profesor? ¿Por qué?

4. ¿Qué recomendaciones daría para tener un sistema eficiente de comunicación electrónica profesor-alumno para ofrecer correcciones a trabajos escritos? 